\title{
The Impact of Micro Finance and Skill Training Intervention on Single Women's Vulnerability in Nepal
}

\author{
Raghu Bir Bista* \\ Assistant Professor Tribhuvan University Nepal \\ *Corresponding Author \\ Raghu Bir Bista \\ Article History \\ Received: 02.10.2019 \\ Accepted: 09.10.2019 \\ Published: 27.11 .2019
}

\begin{abstract}
Micro finance and skill training are integrated to build empowerment model to improve socio economic level of single women in Nepal. This popular model is widely employed to improve socio economic empowerment of women, particularly single women for restore and rehabilitate their life from this psychological trauma and vulnerability. Its result is claimed positive. In this context, this paper examines whether the skill training and micro finance improves to empower single women socio economically and to reduce poverty and vulnerability and happiness of single women in Nepal through descriptive statistics and the paired "t" test. Its primary data sets are collected from the survey. The " $\mathrm{t}$ " test is significant that the skill training and micro finance are effective measures to empower single women socio economically and to reduce their vulnerability and then improve their self-reliant and happiness.
\end{abstract}

Keywords: skill training, micro finance, poverty, vulnerability, happiness, single women, Nepal etc.

Jel Code: G2, G4, G5, I3,

\section{INTRODUCTION}

Studies and fact figures on that issue in the world wide show single women as socio economic vulnerable people lying below the poverty line of nation. In various studies of UN, there are 245 million widows worldwide. Out of total widows, 150 million widows live under the poverty line. In Nepal, its figure has reached at 0.5 million widows in the country. Day by day, its trend is inclining because of inclining trend of male deaths per year induced by war, internal conflict, socio-ethnic conflict and accidents in the country. Thus, a single woman is a root trauma factor and indicator of poverty.

Single women within household is identified as a hidden, sensitive and serious issue. It is conceptualized by World Human Right [1] as a widow, divorce, separated or an unmarried woman over 35 years. In 2003, it was observed as young aged single women having harassment issue. Parajuli [2] have similar note but consider currently divorced, widowed or have always been single, as well as unmarried cohabiters. Thus, single women broadly refer single women at any age.

Over long decades, such issue was not much more talked and not considered as a big issue because of its hidden domain, social codes and practices and misunderstanding on its multidimensional factors. If we observe status of single women, they are blamed as husband eaters and stigmatized as inauspicious and witches [3]. Thus, single women are socially complexed and economically vulnerable issue producing women poverty.

In Nepal, single woman has different circumstances in which early marriage is considered as a good cause behind it in many literatures in which early marriage reduces life time for education and other ability earning. Bernstein [4] notes that most single woman has early marriage by dropping her schooling. Further, he argues that single woman has obstacles of ability including employment, access to the market, skill trainings break out the cycle of poverty. Furthermore, her inability and independence makes herself marginal and silent against any exploitation. Giri[5] explains her problems such as sexual harassment. She cannot react publically and privately due to fear of losing job, of livelihood source and of social status and feelings of shame. Fact and figures indicate 66 percent

Copyright @ 2019: This is an open-access article distributed under the terms of the Creative Commons Attribution license which permits unrestricted use, distribution, and reproduction in any medium for non commercial use (NonCommercial, or CC-BY-NC) provided the original author and source are credited. 
verbal abuse and 33 percent emotional abuse [6]. In addition, out of 57 percent women, 11 percent of single women in Nepal are literate [7]. Lohani [8] mentions that single women are usually deprived of their husband's property left to face discrimination, stigma, forcing them into poverty. Thus, single woman issue is considered a complicated issue to be needed urgently addressed.

Based on the indicators of women empowerment: their access to knowledge, economic resource and political power as well as their personal autonomy in the process of decision making, the government of Nepal has been initiating women empowerment policy and program since 1990s [9]. There are two simultaneous modules: constitutional and legal provisions to make guarantee women's rights on resources, property, opportunity, decision making process etc. and empowerment programs including advocacy, skill training, informal literacy, information about women's right, institutional development etc. In Nepal, quota approach is used to women's inclusion in women's representation, participation and decision-making process from local government level to the parliament. In 2017, women representatives from local government to the parliament are 40 percent all over the country [10]. Such reflection can be found in development plan and policies from national level to local level. Its example is socio economic inclusion to women, particularly single women in women empowerment programs. In 2002, micro finance and capacity building were major women empowerment and poverty reduction tools from 1990s to 2000s after the establishment of Regional Rural Development Banks (RRDB) with the objective to provide micro finance services and capacity building to women and marginal poor. Soon after 2000s, NGOs and Private Micro Finance were licensed. NGOs have employed microfinance and capacity building as major intervention to women empowerment and development. HDI 2019 provides a strong evidence of the growth of socio-economic status of women. In this context, this paper assesses whether the vulnerability level of single woman is influenced by various socio-economic factors or not, and whether skill training and micro finance have contributed to reduce the vulnerability of single woman and her role within the household in the society.

This paper is organized into sections. Section 1 introduces the context of single woman in Nepal. Similarly, section 2 explains objectives of the study; section 3 explains data and method of this study containing primary data (household survey and Focused Group Discussion (FGD)) and source of data. Section 4 presents results of the case of single woman in Nepal.

\section{OBJECTIVES}

This paper assesses broadly the impacts of micro finance and skill training on single woman within household in the society in Nepal. Its specific objectives are as follows: to examine the vulnerability level of single woman and its socio-economic factorial contribution and find out the impacts of skill training and microfinance on the vulnerability level of single woman within household in the society.

\section{Data And Method}

This study is case study method based on explorative and descriptive research design to assess the vulnerability level of single woman and its capacity building and micro finance impacts in rural village in Nepal by studying case of Ramkot and Bhimdhunga VDC. Its data sets of this study used primary and secondary. In case of Primary Data of Individual's perspective and responses, household survey and focused group discussion, the interview method and observation method were applied in the selected VDCS.

The sample selection method followed the principle of random sampling method in which out of total single woman population (261 as recorded in two VDCs), about 15 percent sample (that is 40 single women) was selected. In case of household selection, there was used lottery method after numbering households in above VDCs. The sample was interviewed with structured questionnaire.

The secondary data was collected from CBS [10], District Profiles [11], VDC profiles [12] and other relevant sources: women's profile of CBS [7].

\section{STUDY AREA}

Nepal is the landlocked country emerging new republican country between two giants: China in North and India in East, South and West in South Asia. Demographically, women population (51\%) leads to male population (49\%) in accordance with Population Census. However, there are identified various different socio economic and gender issues related to women in which single woman issue is considered as major issue in Nepal from all perspectives. 


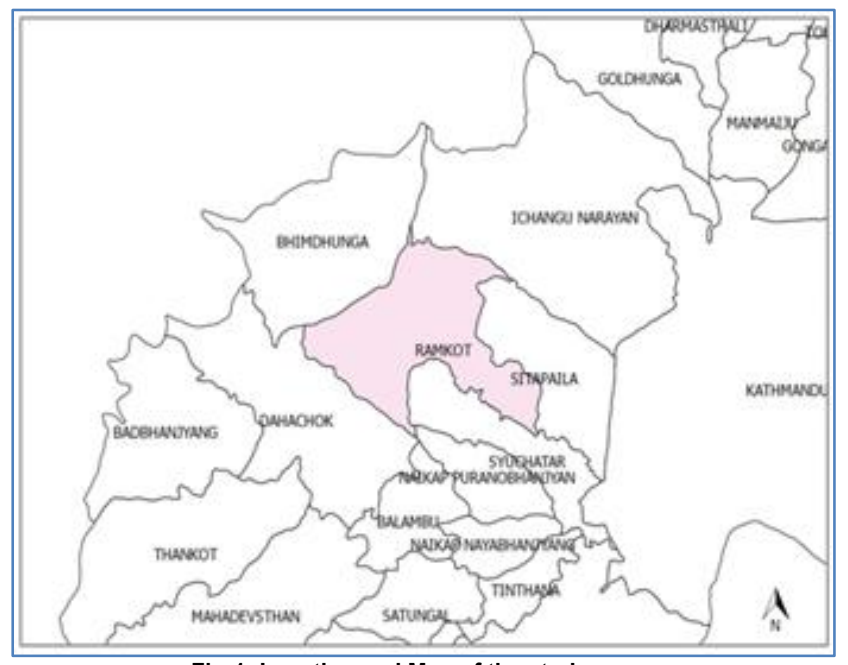

Fig-1: Location and Map of the study areas

Source: CBS 2011 VDC/Municipality profile

In Kathmandu, the study areas: Ramkot and Bhindhunga VDCs are two VDCs of Kathmandu Districts which are located 10 $\mathrm{km}$ far at the western side of Kathmandu Metropolitan City.

- Ramkot VDC is the areas of 5.8 square kilometer in which 1937 households with 8759 population [7] occupy. Family size is 4.52 that are lower than national family size of 5 . By sex, there is 50.2 percent male and 49.8 percent female. It is little bit reverse with national sex ratio. There is a single woman of 2 percent at VDC level.

- Similarly, Bhindhunga VDC is the area of 6.1 square kilometer in which 619 households with 2915 population [7] occupy. Family size is 4.71 that is lower than national family size of 5 and greater than Ramkot VDC. By sex, there is 50.9 percent male and 49.1 percent female. It is little bit reverse with national sex ratio. There is a single woman of 2.8 percent at VDC level.

\section{Tools of Analysis}

Descriptive statistics and Paired "t" Statistics are employed to examine the vulnerability level of single women and the impact of micro finance and skilled training on the socio-economic level of single women.

\section{Results And Discussions}

Table-1: Socio economic character of single women

\begin{tabular}{|l|c|c|c|c|}
\hline $\begin{array}{l}\text { Socio-economic } \\
\text { character of single } \\
\text { woman }\end{array}$ & $\min$ & $\max$ & mean & $\begin{array}{c}\text { standard } \\
\text { deviation }\end{array}$ \\
\hline Age (years) & 39 & 71 & 53.48 & 10.04 \\
\hline $\begin{array}{l}\text { Female Head in } \\
\text { Household/family }\end{array}$ & 0 & 1 & 0.38 & 0.49 \\
\hline Age Group(years) & & & & \\
\hline Below 60 & 39 & 59 & 44.4 & \\
\hline $60-70$ & 60 & 67 & 59 & \\
\hline Above 70 & 70 & 71 & 70.5 & \\
\hline Source: Field Survey, 2017
\end{tabular}

\section{Socio economic characters}

HH size and structure: Single women are understood as vulnerable section socio economically. In other words, they are the poor households. In general, nuclear households have smaller family size than the joint family. There are family sizes of 3.75 less than national average family size of 5.4[7]. In case of the joint family and the poor family of single women, there is outlier of 8 person's family size in maximum. It may be a good source of labor endowments. In minima, there is outlier of 1-person family size (Table-2). 
Table-2: Household size and structure

\begin{tabular}{|c|c|c|c|c|}
\hline $\begin{array}{c}\text { Household size and } \\
\text { structure }\end{array}$ & $\min$ & $\max$ & mean & $\begin{array}{c}\text { standard } \\
\text { deviation }\end{array}$ \\
\hline Sex & & & & \\
\hline Male & 0 & 4 & 1.37 & 1.08 \\
\hline Female & 1 & 5 & 2.37 & 1.18 \\
\hline Family Size & 1 & 8 & 3.75 & 2.01 \\
\hline No of Children & 0 & 4 & 1.12 & 0.91 \\
\hline
\end{tabular}

Source: Field Survey, 2017

Similarly, sex factor is another character of single women's $\mathrm{HH}$ in which female in mean (2.37) dominates highly to male in mean (1.37). In minima, there is found zero male. In maxima, female's representation of 5 in HH is greater than male's (4)(Table-2).

Age distribution of single women is found in minima of 39 years and in maxima of 71 years. Its mean age is 53.48 years. When its age distribution is categorized into below 60,60 to 70 and above 70 , there is found 62.5 percent $\mathrm{HH}, 32.5$ percent $\mathrm{HH}$ and 5 percent $\mathrm{HH}$ respectively (Table-1).

Female Head in $\mathrm{HH}$ has decisive factor in decision making process within family and Household. There is found 38 percent household having female head (Table-1). It reflects size of nuclear family also.

Table-3: Landholding and Livestock endowments

\begin{tabular}{|c|c|c|c|c|}
\hline $\begin{array}{c}\text { Landholding and } \\
\text { livestock }\end{array}$ & $\min$ & $\max$ & mean & $\begin{array}{c}\text { standard } \\
\text { deviation }\end{array}$ \\
\hline Landholding(Ropani) & 0 & 3 & 1.72 & 1.08 \\
\hline $\begin{array}{c}\text { Irrigational land } \\
\text { No irrigational land }\end{array}$ & 0 & 4 & 1.92 & 1.18 \\
\hline Cows & 0 & 2 & 0.3 & 0.52 \\
\hline Goats & 0 & 4 & 2.15 & 1.09 \\
\hline
\end{tabular}

Source: Field Survey, 2017

\section{Resources Endowments}

There are two major resources endowments: landholding and livestock presented in table-3. In land, there are two characters: irrigational and non-irrigational. Each household holds 1.72 ropani in average in irrigational land and 1.92 ropani in average in non-irrigational land. In sum, each household holds 3.62 ropani in average. In case of non-irrigational land, each household has challenges. Similarly, there are two livestock including cow and goats. Each household traditionally farms two cows in maxima only for milk and composite fertilizers and four goats in maxima only for milk and meat production. In practice, livestock is attaché of traditional Nepalese households, like as single women's household (Table-3).

Table-4: HH categories in socioeconomic characters

\begin{tabular}{|c|c|c|c|c|c|}
\hline HH categories & HH No & $\min$ & $\max$ & mean & standard deviation \\
\hline Food Sufficiency & 40 & 2 & 12 & 8.75 & 3.84 \\
\hline$<3$ months & 9 & & & & \\
\hline$<6$ months & 4 & & & & \\
\hline$<9$ months & 4 & & & & \\
\hline$<12$ months & 23 & & & & \\
\hline \multicolumn{6}{|l|}{ Economic } \\
\hline Poor & 13 & & & & \\
\hline Ultra poor & 9 & & & & \\
\hline Rich & 18 & & & & \\
\hline Literacy & 40 & 0 & 1 & 0.5 & 0.506 \\
\hline \multicolumn{6}{|l|}{ Education } \\
\hline Literate & 20 & & & & \\
\hline Illiterate & 20 & & & & \\
\hline \multicolumn{6}{|l|}{ Sex } \\
\hline Male & & 0 & 4 & 1.37 & 1.08 \\
\hline Female & & 1 & 5 & 2.37 & 1.18 \\
\hline
\end{tabular}




\section{Socio economic character of single women}

A single woman is vulnerable section within the family in the society of Nepal. To understand their socio economic status, there is used food sufficiency, economic and social indicators. Education is social indicator indicating capacity of single women. There are just two categories: just literate (who can read, sign and write her name) and illiterate (who cannot read, sign and write her name, except understanding Nepali language). There are found 50-50 percent distribution between just literate and illiterate. In case of economic condition, there are three categorizations: rich, relative poor and poor. There are 45 percent well off rich group. Then, there are 55 percent of the poor (32.5 percent) and the ultra-poor (22.5 percent) in sum (Table-4).

Similarly, food sufficiency categorizes poverty level by dividing four groups of food sufficiency based months: less than 3 months, less than 6 months, less than 9 months and less than 12 months and equivalent. There are 22.5 percent less than 3 months, 10 percent less than 6 months, 10 percent less than 9 months and 57.5 percent less than 12 months and equivalent (Table-4).

\section{Poverty and Vulnerability level of Single women}

Vulnerability is a state of inability to self-protection and recovery from social, economic and natural shocks. Literatures Aysen[13] and Philip and Rayhan[14] identify its causes: illiteracy, hunger, fragile and hazardous location, gender discrimination, no access to resources and decision making process.

With Poverty, Philip and Rayhan[14] argues that despite different implications of poverty and vulnerability, poverty is generally associated with deprivation of health, education, food, knowledge, influence over one's environment etc. It creates vulnerability. The poor are more vulnerable than any other group to health hazards, economic down turns, natural catastrophes and even man made violence, along with shocks (illness, injury and loss of livelihood). Abuka et al. [15] notes that High incidence of poverty contributes significant amounts of insecurity in the people. Thus, poverty and vulnerability level are correlated each other.

Table-5: Food Sufficiency

\begin{tabular}{|r|c|c|c|c|}
\hline HH categories & HH No & $\begin{array}{c}\text { Mean HH } \\
\text { size }\end{array}$ & $\begin{array}{r}<12 \\
\text { months }\end{array}$ & $\begin{array}{r}12 \\
\text { months }\end{array}$ \\
\hline Economic & & 13 & \\
\hline Poor & 13 & & 9 & \\
\hline Relative poor & 9 & & & 18 \\
\hline Rich & 18 & & 20 & 20 \\
\hline
\end{tabular}

Source: Field Survey, 2017

\section{Measure of poverty level}

There are different reference lines of poverty level based on different approaches at household level. One of well used and popular approach is the reference of 12 months of food sufficiency. If household meets 12 months food sufficiency, such household is categorized no poverty. However, less than 12 months food sufficiency measures extremity of poverty level. There are three extreme reference points: less than 12 months, less than 9 months, less than 6 months and less than 3 months. Table 4 shows distribution of households and single women. Out of 100 percent single women $\mathrm{HH}$, there is 57.5 percent single woman having less than 12 months food sufficiency in which 22.5 percent less than 3 months is more highly vulnerable, 10 percent less than 6 months is highly vulnerable, 10 percent less than 9 months is vulnerable and 14 percent less than 12 months is less vulnerable than of less than 9 months, less than 6 months and less than 3 months food sufficiency (Table -5 ).

Table-6: Vulnerability level of Single Women

\begin{tabular}{|c|c|c|c|c|c|}
\hline \multirow[t]{2}{*}{ Vulnerability Indicator } & $\begin{array}{l}\text { Nuclear } \\
\text { Family }\end{array}$ & & $\begin{array}{l}\text { Joint } \\
\text { Family }\end{array}$ & & \multirow[t]{2}{*}{ Total } \\
\hline & Yes & No & Yes & No & \\
\hline \multicolumn{6}{|l|}{ Social } \\
\hline Discrimination & 0 & 15 & 25 & 0 & 40 \\
\hline Exclusion & 0 & 15 & 25 & 0 & 40 \\
\hline Sexual Harassment & 15 & 0 & 10 & 15 & 40 \\
\hline Emotional Torture & 0 & 15 & 20 & 5 & 40 \\
\hline No Access to Resources & 0 & 15 & 20 & 5 & 40 \\
\hline No Participation in Household Decision Making & 0 & 15 & 22 & 3 & 40 \\
\hline No Participation in Community Decision Making & & 15 & 19 & 6 & 40 \\
\hline Total & 15 & 90 & 141 & 34 & 280 \\
\hline
\end{tabular}

Source: Field Survey, 2017

Measure of vulnerability level: There are different approaches and factors measuring level of vulnerability. Above poverty level shows us the vulnerability level of single women. In addition, there are applied the following factors as supplementary factors to 
poverty: social factors (discrimination and exclusion), sexual harassment, and emotional torture, no access to resources (land, money, information, organization etc.), no participation in household decision making process and no participation in community decision making process(see its details in table 6). There are presented two cases: nuclear family and joint family. In nuclear family where female is head, there are not social discrimination and exclusion found in 38 percent in nuclear family within household because single woman has a right to take decisions in which single woman is free to access to resources and participation in decision making process within household and in the community. In this case, a single woman is less vulnerable from social factors. However, in case of sexual harassment, there is found because single woman has not only internal activities but also external activities like as male.

In case of joint family, male is a head following social codes, norms and values as practiced in the society for social prestige of the family. Therefore, single woman is not free like as female head nuclear family. Single woman is not considered as good fortune. Therefore, she is excluded from every socio-religious activities. In case of food, dress up etc., she is discriminated. In this case, 62.5 percent single women in the joint family perceives socially discriminated and excluded. Except few cases, out of 62.5 percent, about 50 percent single women think in emotional torture, no access to resources, no participation in household decision making process and community level decision making process. In case of sexual harassment, except 25 percent single women, 38 percent single women feel no sexual harassment because single women don't need to work outside and they have male protection. However, if we observe the level of vulnerability, the vulnerability of single women in the joint family headed by male is higher than in the nuclear family headed by female. From poverty, majority of single women are extremely vulnerable.

\section{The impacts of Skill Training and Micro Finance Activities}

In recent years, single women's vulnerability and poverty are identified as critical issue to be addressed seriously and specifically from holistic approach to women issue and then the government and Non-government agencies have intervened in two aspects: skill training and micro finance to single women group. In the skill training, these agencies have conducted two staged activities: advocacy about women's right and gender issues at first stage and women's empowerment at second under which single women are provided different training on micro enterprises related skills and techniques for income generation(such as commercial vegetable farming, tailoring, knitting, painting, pickle making and others). They have organized at general and at group level. After then, these NGO have made single women groups for microfinance activities in which NGO provides seed money and skill training about micro finance with its objectives, uses and importance. There is three single women's group involving actively in micro enterprises and micro finance over 5 years.

To capture the impact of above interventions particularly in single women groups on their poverty and vulnerability, the statistical tool, the paired "t" test is applied.

\section{Hypothesis formulation and testing}

Let's find whether the skill training and micro finance program is effective to reduce poverty and vulnerability of single women within the family within household in Nepalese society, particularly in the study areas. Let's suppose Null hypothesis is the skill training and microfinance program is not effective to reduce poverty and vulnerability of single women that is $H_{0}: \mu_{d}=0$. Its alternative hypothesis is the skill training and microfinance program is effective to reduce poverty and vulnerability of single women that is $H_{a}: \mu_{d} \neq 0$.

Symbolically, hypothesis at significance level $(\alpha=0.05)$ is presented as below.

Null Hypothesis: $\mathrm{H}_{0}: \mu_{\mathrm{d}}=0$

Alternative Hypothesis: $\mathrm{H}_{\mathrm{a}}: \mu_{\mathrm{d}} \neq 0$

\section{Descriptive Statistics}

The skill training and micro finance program of NGO have certainly brought changes in the life of single women. To measure the effectiveness of the skill training and micro finance program to reduce poverty and vulnerability of single women within the family, there are different factors having four major measures: time allocation inside and outside house and in capacity building, use of micro finance and income generation per month. Time allocation inside and outside house and Time allocation in skill training is measured by using time measure of hours. In case of microfinance, its unit is Rupees like as Income Generation per month.

In four factors: time allocation inside and outside house, Time allocation in skill training, microfinance and income generation from enterprises activities, there are used two time periods including pre and post of the skill training and micro finance programs for measuring change between pre and post time periods in the life, activities and behavior of single women in the family within household. Table 7 shows that how much change in these two time periods: pre and post time through mean.

Time allocation measures behavior and preference of single women. If single women give more time, it means more preference. If single women give less time, it means less preference. In the time allocation of single women in kitchen inside household, mean hour of pre time period of the program is 7.88 hours. Kitchen receives more preference of single women. It is higher than mean hour of post time of the program (4.38 hours). Thus, single women's time allocation in kitchen in the post of the program is 
less by 3.5 hours. In other words, single women give less preference in kitchen in the post of the program than other activities because the skill training and micro finance program has given alternatives to single women more than kitchen (Table 7).

Table-7: Descriptive statistics and Correlation

\begin{tabular}{|c|c|c|c|c|c|}
\hline Time allocation of Single woman & Mean & Std. deviation & Std. Error Mean & Correlation & sig \\
\hline \multicolumn{6}{|l|}{ In Kitchen } \\
\hline Inside household (before) & 7.88 & 1.842 & 0.291 & \multirow[b]{2}{*}{0.68} & \\
\hline Inside household (after) & 4.38 & 0.868 & 0.137 & & \\
\hline \multicolumn{6}{|l|}{ Social Activities } \\
\hline Outside household (before) & .32 & .432 & .068 & \multirow{2}{*}{.112} & \multirow{2}{*}{0.492} \\
\hline Outside household (after) & 2.50 & .531 & .084 & & \\
\hline \multicolumn{6}{|l|}{ Skill Training } \\
\hline Outside household (before) & .22 & .423 & .067 & \multirow[b]{2}{*}{.262} & \multirow[b]{2}{*}{0.103} \\
\hline Outside household (after) & 1.90 & .67 & .106 & & \\
\hline \multicolumn{6}{|l|}{ Use of Micro } \\
\hline Enterprises (before) & 12.75 & 39.09 & 6.181 & \multirow{2}{*}{-.202} & \multirow{2}{*}{0.211} \\
\hline Enterprise (after) & 4577.5 & 2090.208 & 330.491 & & \\
\hline \multicolumn{6}{|l|}{ Income generation } \\
\hline before & 677.50 & 240.179 & 37.976 & \multirow{2}{*}{-.142} & \multirow{2}{*}{.381} \\
\hline after & $1.39 \mathrm{E} 4$ & 6221.551 & 983.714 & & \\
\hline
\end{tabular}

Source: calculated outcomes based on field survey, 2017

Similarly, time allocation of single women outside household activities (social and economic activities) measures how single women improve their confidence, capacity and preference. If single women increase time in hours, they have more social and economic activities outside household by rejecting social codes, norms and values binding to single women. Before the program, single women have given less time in hours per day by following social codes, norms and values. Its mean is 0.32 hours per day. After the program, they have allocated 2.5 hours mean time per day for participating training and advocacy activities. It shows changes in their preference, behavior and time allocation. Out of total time allocation outside households, single women have allocated 1.9 mean hours per day (Table 7 ).

Single women have not access to resources in the family within household. If they work inside and outside household, they will not get any wages because such work is generally defined as socio economic responsibility within household. In addition, single women are socio economically discriminated and exploited in the family. In another words, they have ignorance only after the death of husband. However, there is not alternative. Therefore, they have used 12.75 rupees per month in average. It is nearly zero per month. After the intervention of micro finance groups, single women have started to use micro finance for different economic entrepreneurial activities after getting training and knowledge. In the post of such intervention, single women are capable to use 4577.5 rupees per month in average for entrepreneurial activities (Table 7). It is a positive change in access to resources and capacity to take right decision in resource allocation for household or desire.

Generally single women have not allocated their time on traditional activities (cooking, cleaning, working in land etc.) within household. For their work and time allocation, they could not receive any rupees, except food, accommodation, security and social prestige. They are very far from resources and decision making process, although they have desire to access to resources and allocate such resources. However, in the pre time period, they have not such opportunity and preference. Therefore, they are economically vulnerable. At the pre time period, they have earned 677.5 rupees per month in average. After getting entrepreneurial trainings and micro finance services, single women have changed their preference and desire for generating income per month through vegetable farming, tea stall, retailing etc. Their mean income per month is 13900 rupees. It is a big change activities (see its details in table 7).

\section{Estimation of the Paired $t$ test}

- The paired "t" test-1: Change in time allocation inside and outside household

In this paired $t$ test -1 , whether the change in time allocation of single women inside household activities (cooking, cleaning, water collection etc.) and whether the change in time allocation of single women outside household and also participation in social activities and training occur in two time period samples of time allocation of single women in kitchen is tested by running SPSS- 16 . Table- 8 shows there is a difference between two periodic samples by 3.5 hours in case of time allocation of single women inside household work. Its t value is estimated 15.857 at 0.05 percent significant level. 
Table-8: Estimated results of Paired "t" test

\begin{tabular}{|c|c|c|c|c|c|c|c|}
\hline \multirow[t]{3}{*}{ Diff } & \multicolumn{5}{|c|}{ Paired Differences } & \multirow[t]{3}{*}{$t$} & \multirow{3}{*}{$\begin{array}{l}\text { p Sig. (2- } \\
\text { tailed) }\end{array}$} \\
\hline & \multirow[t]{2}{*}{ mean } & \multirow[t]{2}{*}{$\begin{array}{l}\text { Std. } \\
\text { deviation }\end{array}$} & \multirow[t]{2}{*}{$\begin{array}{l}\text { Std. Error } \\
\text { Mean }\end{array}$} & \multicolumn{2}{|c|}{$\begin{array}{l}\text { 95\% Confidence Interval of the } \\
\text { Diff. }\end{array}$} & & \\
\hline & & & & lower & Upper & & \\
\hline before and after & 3.5 & 1.396 & 0.221 & 3.054 & 3.946 & 15.857 & .000 \\
\hline before and after & -2.175 & 0.646 & 0.102 & -2.382 & -1.968 & -21.294 & .000 \\
\hline before and after & -1.675 & 0.694 & 0.110 & -1.897 & -1.453 & -15.268 & .000 \\
\hline before and after & $-4.565 \mathrm{E} 3$ & 2094.46 & 331.79 & -5235.87 & -3893.62 & -13.758 & .000 \\
\hline before and after & $-1.322 \mathrm{E} 4$ & 6260.23 & 989.83 & -15224.61 & -11220.38 & -13.358 & .000 \\
\hline
\end{tabular}

Source: calculated outcomes based on field survey, 2017

Similarly, there is a difference mean between two periodic samples of outside household time allocation of single women by -2.175 hours. Its $t$ value is estimated -21.294 at 0.05 percent significant level. Out of time allocation household activities, there is an included training activity. In this test, there is difference mean time allocation of single women in social activities and training activities outside household by -1.675 . Its $t$ value is -15.294 at 0.05 percent significant level.

\section{- The paired " $t$ " test-2: Change in use of micro finance for entrepreneur activities}

In this paired $t$ test -3 , whether the change in participation and use of micro finance of single women for entrepreneurial activities inside and outside household occur in two time period samples of micro finance money used by single women is tested by running SPSS-16. Table- 8 shows there is a difference between two periodic samples by -4565 rupees per month in case of finance used by single women. Its t value is estimated -13.758 at 0.05 percent significant level.

Table-8: Estimated results of Paired " $t$ " test

\begin{tabular}{|c|c|c|c|c|c|c|c|}
\hline \multirow[t]{3}{*}{ Diff } & \multicolumn{5}{|c|}{ Paired Differences } & \multirow[t]{3}{*}{$t$} & \multirow{3}{*}{$\begin{array}{l}\text { p Sig. (2- } \\
\text { tailed) }\end{array}$} \\
\hline & \multirow[t]{2}{*}{ mean } & \multirow[t]{2}{*}{$\begin{array}{l}\text { Std. } \\
\text { deviation }\end{array}$} & \multirow{2}{*}{$\begin{array}{l}\text { Std. } \\
\text { Error } \\
\text { Mean }\end{array}$} & \multicolumn{2}{|c|}{$\begin{array}{l}95 \% \text { Confidence Interval of } \\
\text { the Diff. }\end{array}$} & & \\
\hline & & & & lower & Upper & & \\
\hline before and after & 3.5 & 1.396 & 0.221 & 3.054 & 3.946 & 15.857 & .000 \\
\hline before and after & -2.175 & 0.646 & 0.102 & -2.382 & -1.968 & -21.294 & .000 \\
\hline before and after & -1.675 & 0.694 & 0.110 & -1.897 & -1.453 & -15.268 & .000 \\
\hline before and after & $-4.565 \mathrm{E} 3$ & 2094.46 & 331.79 & -5235.87 & -3893.62 & -13.758 & .000 \\
\hline before and after & $-1.322 \mathrm{E} 4$ & 6260.23 & 989.83 & -15224.61 & -11220.38 & -13.358 & .000 \\
\hline
\end{tabular}

Source: calculated outcomes based on field survey, 2017

\section{- The paired " $\mathrm{t}$ " test-3: Change in Income generating of single women}

In this paired $t$ test -3 , whether the change in income generation of single women from entrepreneurial activities by using micro finance and training inside and outside household occur in two time period samples of income generated used by single women is tested by running SPSS-16. Table- 8 shows there is a difference between two periodic samples by -13220 rupees per month in case of finance used by single women. Its $t$ value is estimated -13.358 at 0.05 percent significant level.

\section{Discussion on the result of the paired " $t$ " test}

As $\mathrm{Ha}$ is one sided, the one tailed test for determining the rejection at 5 percent level of significance which comes to as under using table of $t$-distribution for 39 degree of freedom

\section{Table: 1.960}

In the paired test-1, the observed (calculated) value of $t$ for the paired $t$ test- 1 is 15.857 which are greater than the $t$ tabulated value $1.960(15.857 \geq 1.960$, p-values $\approx 0.000 \leq 0.05=\propto)$ falls in the rejection region and thus null hypothesis $\mathrm{H}_{0}$ at 5 percent level and the difference in time allocation of single women inside household activities between pre and post the intervention is significant. Similarly, in the outside household, the observed (calculated) value of $t$ for the paired t test-1 is -21.294 which are greater than the $t$ tabulated value $1.960(-21.294 \geq 1.960$, p-values $\approx 0.000 \leq 0.05=\propto)$ falls in the rejection region and thus null hypothesis $H_{0}$ at 5 percent level and the difference in time allocation of single women outside household activities between pre and post the intervention is significant.

Similarly, in skill training activities, the observed (calculated) value of $t$ for the paired t test- 1 is -21.294 which are greater than the $t$ tabulated value $1.960(-15.268 \geq 1.960$, $p$-values $\approx 0.000 \leq 0.05=\propto)$ falls in the rejection region and thus null hypothesis $H_{0}$ at 5 percent level and the difference in time allocation of single women in skill training activities outside household activities between pre and post the intervention is significant. 
Use of micro finance in results of the paired test-2 and Income generation per month in the results of the paired test-3, the observed (calculated) value of $t$ for the paired t test-2 and 3 are -13.758 and -13.358 which are greater than the tabulated value $1.960(-13.758 \geq 1.960$, $p$-values $\approx 0.000 \leq 0.05=\propto$ for the paired $t$ test -2$)$ and $(-13.358 \geq 1.960, p$-values $\approx 0.000 \leq 0.05=\propto$ for the paired $t$ test -2 ) respectively fall in the rejection region and thus null hypothesis $\mathrm{H}_{0}$ at 5 percent level and the difference in the use of micro finance and income generation of single women between pre and post the intervention are significant.

\section{CONCLUSION}

The program of skill training and micro finance particularly for single women initiated by NGO is used to socio economic empowerment of single women for reducing their poverty and vulnerability level in Nepal. Above results of all factors (time allocation inside and outside household, time allocation in training, use of micro finance and income generation per month) have rejected null hypothesis and accepted alternative hypothesis that is there is significant difference in means in all these factors. It means the program of skill training and micro finance particularly for single women is effective to empower single women socio economically and to reduce poverty and vulnerability and to improve self-reliant and happiness of single women.

\section{REFERENCE}

1. WHR. (2009). Problems and Challenges of Single Women (Widows) in Nepal. Kathmandu: Action Aid and Women for Human Rights, Single Women Group.

2. Parajuli, K. (2008). Nepal: Muslim women in the street against 'talak' divorce. http://www.wluml.org/node/4911

3. Thapa, L. (2007). Nepal's widow: 16 days against gender violence. http://www. opendemocracy.net/blog/nepals_widows

4. Berinstein, K. (2006). Introduction: The Situation on Widows: SAAPE Newsletter. Volume 3 Issue1, January-April

5. Giri, V.M. (2000). Transforming approached to conflict resolution. www.capwip.org/ resources/womparlconf2000/downloads/ giri1.doc

6. Unicef. (2001). Early marriage: child spouses.

7. CBS. (2011). Women in Nepal: Some Statistical Facts. Kathmandu: Central Bureau of Statistics.

8. Lohani, S.N., \& K.K.C. (2001). "Women in Sustainable Agriculture Development and Environment." Agriculture and Environment 2001: World Wide Web of Life - Communication Issue, pp. 7-14. Kathmandu: Ministry of Agriculture and Cooperatives

9. UNDP. (1997). Human Resource Report. New York: Oxford University Press.

10. CBS. (2001). Population Census. Kathmandu: Central Bureau of Statistics.

11. District Profile. (2015). Kathmandu District Profile. Kathmandu: District Office

12. VDCs profile. (2013). Ramkot VDC Profile. Ramkot: VDC

13. Aysen, Y.F. (1993). "Keynote Paper: Vulnerability Assessment”. In: P Merriman and C.Browitt, eds., Natural Disaters: Protecting Vulnerable Communities, 1-14

14. Philip, D., \& Rayhan, I. (2004). Vulnerability and Poverty: what are the causes and how are they related? Term paper, Bonn: ZEF

15. Abuka, C. A., Atingi-Ego, M., Opolot, J., \& Okello, P. (2007). Determinants of poverty vulnerability in Uganda. 